\title{
Prevalence of antibodies to Chlamydia trachomatis, Neisseria gonorrhoeae, and Mycoplasma hominis in infertile women
}

\author{
K H TJIAM,* G H ZEILMAKER, $†$ A TH ALBERDA, $\neq$ B Y M VAN HEIJST, $\S$ \\ J C DE ROO,§ A A POLAK-VOGELZANG, II TH VAN JOOST,* E STOLZ,* \\ AND M F MICHEL§ \\ From the Departments of *Dermatovenereology and $¥$ Obstetrics and Gynaecology, University Hospital, \\ Rotterdam, the Departments of + Physiology and §Clinical Microbiology and Antimicrobial Therapy, \\ Erasmus University, Rotterdam, and the II National Institute for Public Health and Environmental \\ Hygiene, Bilthoven, the Netherlands
}

SUMMARY A total of 57 infertile women, who had been referred for in vitro fertilisation or for diagnostic laparoscopy, were tested for the presence of antibodies to Chlamydia trachomatis, Neisseria gonorrhoeae, and Mycoplasma hominis. Four were excluded from the study. Of the remaining 53, 33 had laparoscopically obvious tubal disorders, such as adhesions, distal occlusions and strictures, and 20 did not. Antibodies to $C$ trachomatis were found in $7 / 33(21 \cdot 2 \%) v 0 / 20$, antibodies to $N$ gonorrhoeae in 20/38 (60.6\%) $v 5 / 20(25 \%)$, and antibodies to $M$ hominis in $18 / 24(75 \%)$ women with tubal disorders $v 13 / 19(68 \cdot 4 \%)$ of those with no disorder. Antibodies to $C$ trachomatis and $N$ gonorrhoeae were significantly $(\mathrm{p}<0.05)$ more common in women with tubal disorders. The high prevalence of antibodies to $N$ gonorrhoeae in infertile women without tubal disorders suggests that ciliated tubal epithelium is damaged after inflammation without this being laparoscopically visible. Our results confirm the important role of $N$ gonorrhoeae and $C$ trachomatis in the aetiology of infertility after tubal inflammation.

\section{Introduction}

Salpingitis may lead to tubal infertility, the relative risk of which, after one or more episodes of salpingitis, varies between $12 \cdot 8 \%$ and $75 \% . .^{12}$ Moreover women who have had salpingitis have a sevenfold to tenfold risk of ectopic pregnancy. Tubal damage after infection is estimated to be an aetiological factor in $30 \%$ to $40 \%$ of infertile women. ${ }^{2}$ Most cases of salpingitis are caused by the ascending spread of infection from the lower genital tract. Acute salpingitis has a polymicrobial aetiology. Anaerobic micro-organisms such as Peptostreptococcus, Peptococcus, Clostridium, and Bacteroides species have been isolated, either individually or in combination with $N$ gonorrhoeae, $M$ hominis, or $C$ trachomatis. $^{3}$ The relative importance of these organisms as causative agents has not been agreed. In the United States gonococci and anaerobes are more commonly associated with salpingitis than in

Address for reprints: Dr K H Tjiam, Department of Dermatovenereology, University Hospital, Rotterdam, the Netherlands

Accepted for publication 12 September 1984
Sweden $^{4}$ and France, ${ }^{5}$ where most isolates yield $C$ trachomatis. These differences in the prevalence of causative organisms may be attributed to epidemiological factors, the length of time after infection, and the methods used for taking specimens for culture. Moore et al showed antibodies to $C$ trachomatis in $73 \%$ of infertile women with distal tubal occlusion, but antibodies could not be detected in women with normal tubes. ${ }^{6}$ Punnonen et $a \Gamma^{7}$ and Conway et $a l^{8}$ made similar observations. These studies did not, however, evaluate antibodies to $M$ hominis or $N$ gonorrhoeae.

We undertook the study reported here to assess the relative importance of $N$ gonorrhoeae, $M$ hominis and $C$ trachomatis as organisms causing tubal inflammation leading to infertility by measuring the prevalence of antibodies to these organisms in a group of infertile women.

\section{Patients and methods}

\section{STUDY POPULATION}

We tested serum from 57 women who had been infertile for at least 18 months and had been referred by their doctors to the gynaecological outpatient 
clinic of the University Hospital Rotterdam, the Netherlands for in vitro fertilisation or diagnostic laparoscopy.

\section{CLASSIFICATION OF DISORDERS OF THE FALLOPIAN TUBES}

We regarded the presence of peritubal adhesions, strictures, tubal occlusions, or a combination of these disorders as a macroscopic feature of tubal disease. This was the case in $\mathbf{3 3}$ women, two of whom showed only peritubal adhesions. The 20 women who did not show such abnormalities were considered to be infertile for unknown reasons. Four women had well documented causes of tubal disorders: one had had endometriosis, two had had tuberculous salpingitis, and one had had peritonitis after a perforated appendix. These four women were excluded from evaluation.

\section{INVESTIGATIONS OF INFERTILITY}

We recorded each patient's age and history of pregnancy, salpingitis, pelvic surgery, and the use of an intrauterine device (IUD). Infertility investigations consisted of semen analysis, basal temperature curve, postcoital test, hysterosalpingography, and laparoscopy with intrauterine injection of methylene blue to assess tubal patency.

\section{SEROLOGY TESTS}

We tested serum samples for the presence of antibodies to $C$ trachomatis by the microimmunofluorescence technique of Wang et al. ${ }^{9}$ Six pooled antigens were used: A to C, DE, FG, I, J, and K. A titre of $>1 / 8$ was considered to be positive. Antibodies against gonococcal pili antigens were shown by an enzyme linked immunosorbent assay (ELISA), as described by Oranje et al. ${ }^{10}$ An extinction of $>1 \cdot 15$ was considered to be positive. Anti-human immunoglobulin conjugate was used in both tests.

Antibodies to $M$ hominis were shown by the indirect immunofluorescence method of Rosendal $e t$ al. ${ }^{11}$ A strain of $M$ hominis that had been isolated from a patient served as antigen. Positive control serum was kindly supplied by Dr K Lind (Statens Serum Institut, Copenhagen, Denmark). Serum dilutions of $1 / 40$ and $1 / 80$ were prepared before the test. Anti-human IgG conjugate was used. Serum samples from 25 healthy women blood donors aged 22 to 34 were tested for the presence of the above mentioned antibodies.

\section{STATISTICAL METHODS}

The $\chi^{2}$ method for independent samples was used to assess the level of significance.

\section{Results}

Table I shows that significantly more $(0.01<\mathrm{p}<0.05)$ women with macroscopically visible tubal disorders had antibodies to $C$ trachomatis and to gonococcal pili in their serum than those without such disorders. Positive serology test results for chlamydiae were found in seven $(13.2 \%)$ out of 53 women. In these seven women the most common serogroup was DE (in five women) followed by A-C (in four) and FG (in four), I (in three), and $J$ (in two). In three out of these seven women only one antigen pool could be found. Antibodies to gonococcal pili antigen were present in $25(47 \cdot 2 \%)$ out of 53 women. Antibodies to $M$ hominis were present in $31(72 \%)$ out of 43 women, of whom 18 had tubal disorders and 13 did not. Of the 25 women blood donors, none had antibodies to $C$ trachomatis, one had antibodies to gonococcal pili, and four had antibodies to $M$ hominis.

Table II shows that antibodies to $C$ trachomatis were significantly $(0.01<\mathrm{p}<0.05)$ more common in women with a history of salpingitis. Antibodies to gonococcal pili were also more common in such women, although not significantly so. Antibodies to $M$ hominis were found more commonly in women with secondary infertility than in those with primary infertility. The number of women (nine) with a history of ectopic pregnancy was too small to allow statistical analysis. As the historical data on the use of IUDs were incomplete, these were not evaluated.

TABLE I Demographic, historical, and serological findings in relation to the condition of fallopian tubes as seen at laparoscopy

\begin{tabular}{|c|c|c|}
\hline & Tubal disorder & No tubal disorder \\
\hline $\begin{array}{l}\text { Mean (SEM) age (years) } \\
\text { No }(\%) \text { with secondary infertility } \\
\text { Mean (SEM) duration of infertility (years) } \\
\text { No }(\%) \text { with history of salpingitis } \\
\text { No }(\%) \text { with chlamydial antibodies } \\
\text { No }(\%) \text { with gonococcal antibodies } \\
\text { No }(\%) \text { with chlamydial or gonococcal antibodies, or both } \\
\text { No }(\%) \text { with mycoplasmal antibodies }\end{array}$ & $\begin{array}{l}32 \cdot 0(0 \cdot 7)(\mathrm{n}=33) \\
17 / 33(51 \cdot 5 \%) \\
7 \cdot 4(0 \cdot 8)(\mathrm{n}=31) \\
14 / 20(70 \%) \\
7 / 33(21 \cdot 2 \%) \\
20 / 33(60 \cdot 6 \%) \\
24 / 33(72 \cdot 7 \%) \\
18 / 24(75 \%)\end{array}$ & $\begin{array}{l}31 \cdot 4(0 \cdot 9)(n=20) \\
9 / 20(45 \%) \\
5 \cdot 2(0 \cdot 7)(n=18) \\
1 / 16(6 \cdot 3 \%)^{*} \\
0 / 20(0 \%)^{* *} \\
5 / 20(25 \%)^{* *} \\
5 / 20(25 \%)^{*} \\
13 / 19(68 \cdot 4 \%)\end{array}$ \\
\hline
\end{tabular}

${ }^{*} p<0.001 ;{ }^{* *} 0.01<p<0.05$. 
TABLE II Prevalence of chlamydial, gonococcal, and mycoplasmal antibodies in infertile women related to historical data

\begin{tabular}{|c|c|c|c|c|c|c|c|c|}
\hline & \multicolumn{2}{|c|}{$\begin{array}{l}\text { No }(\%) \text { with chlamydial } \\
\text { antibodies } / \text { No with or } \\
\text { with no history }\end{array}$} & \multicolumn{2}{|c|}{$\begin{array}{l}\text { No (\%) with gonococcal } \\
\text { antibodies/No with or } \\
\text { with no history }\end{array}$} & \multicolumn{2}{|c|}{$\begin{array}{l}\text { No }(\%) \text { with chlamydial or } \\
\text { gonococcal antibodies, or } \\
\text { both/No with or with no } \\
\text { history }\end{array}$} & \multicolumn{2}{|c|}{$\begin{array}{l}\text { No (\%) with mycoplasmal } \\
\text { antibodies/No with or with } \\
\text { no history }\end{array}$} \\
\hline & With history & No history & With history & No history & With history & No history & With history & No history \\
\hline $\begin{array}{l}\text { History of: } \\
\text { Salpingitis } \\
\text { Secondary infertility } \\
\text { Ectopic pregnancy }\end{array}$ & $\begin{array}{l}5 / 14(35 \cdot 7) \\
4 / 29(13 \cdot 8) \\
1 / 9(11 \cdot 1)\end{array}$ & $\begin{array}{l}1 / 23(4 \cdot 3)^{*} \\
2 / 27(7 \cdot 4) \\
6 / 48(12 \cdot 5)\end{array}$ & $\begin{array}{c}9 / 15(60) \\
12 / 29(41 \cdot 4) \\
4 / 9(44 \cdot 4)\end{array}$ & $\begin{array}{r}9 / 23(39 \cdot 1) \\
14 / 27(51 \cdot 9) \\
22 / 48(45 \cdot 8)\end{array}$ & $\begin{array}{c}12 / 15(80) \\
14 / 29(48 \cdot 3) \\
4 / 9(44 \cdot 4)\end{array}$ & $\begin{array}{c}9 / 23(39 \cdot 1)^{*} \\
15 / 27(55 \cdot 6) \\
26 / 48(54 \cdot 2)\end{array}$ & $\begin{array}{c}9 / 14(64 \cdot 3) \\
21 / 27(77 \cdot 8) \\
5 / 8(62 \cdot 5)\end{array}$ & $\begin{array}{l}13 / 21(61 \cdot 9) \\
12 / 24(50) \\
28 / 44(63 \cdot 6)\end{array}$ \\
\hline
\end{tabular}

$* 0.01<\mathrm{p}<0.05$

Table III shows that the predictive value for the presence of macroscopically visible tubal disorders in serum containing chlamydial or gonococcal antibodies, or both, ranged from $64 \cdot 2 \%$ to $94 \cdot 4 \%$.

\section{Discussion}

The prevalence of antibodies to $C$ trachomatis in our patients was low $(13 \cdot 2 \%)$ compared with that (about $30 \%$ ) observed by Moore et al. ${ }^{6}$ Epidemiological differences in the prevalence of chlamydial infections in both populations might offer an explanation for this discrepancy. Moreover, the mean duration of infertility in women in our study with tubal disorders was 7 years and 4 months, and in women without sucin disorders it was 5 years and 2 months. The length of time after infection that antibodies to chlamydiae are demonstrable in man remains to be assessed. Mårdh reported the disappearance of IgG and IgM antibodies after 1 year and 5 months despite initial high titres. ${ }^{12}$ The long duration of infertility may have affected our results. Moore et al found a mean duration of raised titres of four years, which was considerably less time than we found in our study.

The high prevalence of antibodies to gonococcal pili both in the total study population $(47 \cdot 2 \%)$ and in the women with tubal disorders $(60.6 \%)$ was unexpected. Mårdh detected gonococcal antibodies in less than $18 \%$ of 60 women with laparoscopically confirmed salpingitis. ${ }^{4}$ Eschenbach et al, however, found positive serology test results in $84 \%$ of 38 patients with salpingitis and gonococcal cervicitis and in $36 \%$ of 35 patients without current gonorrhoea. ${ }^{3}$

TABLE III Predictive value of positive serology test results for tubal disorders, as seen at laparoscopy

\begin{tabular}{ll}
\hline Serology test results & $\begin{array}{l}\text { Predictive value } \\
\text { within 95\% } \\
\text { confidence limits }\end{array}$ \\
\hline Chlamydial antibodies & $59-100$ \\
Gonococcal antibodies & $59 \cdot 3-93 \cdot 2$ \\
Chlamydial or gonococcal antibodies, or both & $64 \cdot 2-94 \cdot 1$ \\
\hline
\end{tabular}

Our findings suggest a higher prevalence of gonococcal than chlamydial infections at the time of salpingitis. In 248 women who attended the venereal diseases outpatient clinic in Utrecht, the Netherlands in 1979-80, $N$ gonorrhoeae was isolated in $34 \%, C$ trachomatis in $15 \%$, and $M$ hominis in $63 \% .13$ Gonococcal antibodies were found in $25 \%$ of infertile women without laparoscopically obvious tubal disorders. This figure was considerably higher than that for gonococcal antibodies in our blood donors, which may indicate that gross examination by laparoscopy does not detect all tubal abnormalities in patients with tubal infertility. In such patients, dysfunction of ciliated tubal epithelium after inflammation may only be detectable by histopathological investigations. 14 is

Antibodies to $M$ hominis were shown in $72 \%$ of our study population. The prevalence, however, was similar in women with and without tubal disorders (table I). The role of $M$ hominis as a causative organism of salpingitis needs to be established. Animal studies suggest that it has a role in the aetiology of parametritis, rather than salpingitis. ${ }^{17}$

The difference in prevalence of chlamydial antibodies in women with and without a history of salpingitis was striking (table II). Antibodies to gonococcal pili were also more common in women with a history of salpingitis than in those with no such history, but the difference was not significant. In general, salpingitis associated with chlamydiae has a clinically milder course than that caused by gonococci or anaerobes, which seldom remains unnoticed. We cannot explain our results, which contradict this fact.

Our study clearly suggests a role for sexually transmitted organisms in the aetiology of infertility after tubal inflammation. Prospective studies of women with salpingitis, well documented by laparoscopic and bacteriological data, are necessary to gain further insight into the role of several microorganisms in the development of tubal infertility. The high predictive value of the presence of antibodies to chlamydiae or gonococcal pili, or both, for the presence of tubal pathology is worth mentioning. 
Positive serological test results may also be valuable in explaining the aetiology of infertility in women when this is not known. Testing for these antibodies should therefore form a part of every routine infertility investigation.

We thank Mrs P Landsmeer for her technical help.

\section{References}

1. Weström L. Effect of acute pelvic inflammatory disease on fertility. Am J Obstet Gynecol 1975; 121:707-13.

2. Weström L. Incidence, prevalence and trends of acute pelvic inflammatory disease and its consequences in industrialized countries. Am J Obstet Gynecol 1980; 138: 880-92.

3. Eschenbach DA, Buchanan TM, Pollock HM, et al. Polymicrobial etiology of acute pelvic inflammatory disease. $N$ Engl J Med 1975;293:166-71.

4. Mărdh P-A, Lind I, Svensson L, Weström L, Moller BR. Antibodies to Chlamydia trachomatis, Mycoplasma hominis, and Neisseria gonorrhoea in sera from patients with acute salpingitis. British Journal of Venereal Diseases 1981;57: $125-9$.

5. Henry-Suchet J, Catalan F, Loffredo V, et al. Microbiology of specimens obtained by laparoscopy from controls and from patients with pelvic inflammatory disease or infertility with tubal obstruction: Chlamydia trachomatis and Ureaplasma urealyticum. Am J Obstet Gynecol 1980; 138: 1022-5.

6. Moore DE, Foy HM, Daling JR, et al. Increased frequency of serum antibodies to Chlamydia trachomatis in infertility due to distal tubal disease. Lancet 1982; i: 574-7.
7. Punnonen R, Terho P, Nikkanen V, Meurman O. Chlamydial serology in infertile women by immunofluorescence. Fertil Steril 1979; 31:656-9.

8. Conway D, Caul EO, Hull MGR, et al. Chlamydial serology in fertile and infertile women. Lancet 1984; i: 191-3.

9. Wang SP, Grayston JT, Kuo CC, Alexander ER, Holmes KK. Serodiagnosis of Chlamydia trachomatis infection with the microimmunofluorescence test. In: Hobson D, Holmes KK, eds. Non-gonococcal urethritis and related infections. Washington DC: American Society for Microbiology 1977:237-48

10. Oranje AP, Reimann K, van Eijk RW, et al. Gonococcal serology: a comparison of three different tests. British Journal of Venereal Diseases 1983; 59:47-52.

11. Rosendal S, Black FT. Direct and indirect immunofluorescence of unfixed and fixed Mycoplasma colonies. Acta Pathol Microbiol Immunol Scand 1972; B80:615-22.

12. Mårdh P-A. An overview of infectious agents of salpingitis, their biology, and recent advances in methods of detection. Am J Obstet Gynecol 1980; 138: 933-51.

13. Lelijveld JLM, Leentvaar-Kuypers A, Hekker AC, PolakVogelzang AA, de Wit RFE. Sexueel overdraagbare aandoeningen bij bezoeksters van een polikliniek voor geslachtsziekten te Utrecht. Ned Tijdschr Geneeskd 1981; 125:463-6.

14. Patton DL, Halbert SA, Wang SP. Experimental salpingitis in rabbits provoked by Chlamydia trachomatis. Fertil Steril 1982; 37:691-9.

15. Patton DL, Halbert SA, Kuo CC, Wang SP, Holmes KK. Host response to primary Chlamydia trachomatis infection of the fallopian tube in pig-tailed monkeys. Fertil Steril 1983;40:829-40.

16. Moller BR, Freundt EA, Mårdh P-A. Experimental pelvic inflammatory disease provoked by Chlamydia trachomatis and Mycoplasma hominis in grivet monkeys. Am J Obstet Gynecol 1980; 138: $990-5$. 